\title{
Effect of thawing on the quality of frozen mechanically deboned meat
}

\author{
L. RIIHONEN* and P. LINKO**
}

* Finnish Meat Research Centre, Box 56, SF-13101 Hämeenlinna, Finland

** Laboratory of Biotechnology and Food Engineering, Department of Chemical Engineering, Helsinki University of Technology, SF-02150 Espoo, Finland

\footnotetext{
Abstract. The effect of thawing conditions on the quality of mechanically deboned beef (MDB) and mechanically deboned pork (MDP) recovered using a pressure-based Inject Star deboner was investigated. Samples were recovered using a freshly disinfected machine, and immediately packed in $3 \mathrm{~kg}$ portions in high density polyethylene (HDPE)-coated cartons or in Cryovac vacuum bags. Three methods of thawing were used: microwave thawing and thawing at $+4^{\circ} \mathrm{C}$ and at $+21^{\circ} \mathrm{C}$. All samples were analysed chemically and microbiologically immediately after thawing. Microwave thawing resulted in a better quality product $(\mathrm{P}<0.05)$ than thawing at $+4^{\circ} \mathrm{C}$ or at $+21^{\circ} \mathrm{C}$.
}

Index words: mechanically deboned meat (MDM), thawing conditions, microwave thawing

\section{Introduction}

Very few studies on thawing conditions of frozen mechanically deboned meat have been published. SElmeci et al. (1) investigated the differences between microwave and room temperature thawing on mechanically deboned meat from ribs, backbones and leg bones as compared with fresh unfrozen meat. The main differences were in the $\mathrm{a}_{\mathrm{w}}$-values and in the contents of fat, moisture, calcium and phosphate.

Due to the faster thawing technique the moisture contents and the $a_{w}$-values were higher in samples thawed by microwaves than in those defrozen at room temperature. Although the microwave thawing of mechanically deboned meat has not been extensively studied, much work has been done to determine the efficiency of microwaves in the inactivation of microorganisms. Most research reports claim that heat - not microwaves themselves - kills microbes (2).

Moreover, it has also been claimed that microwaves affect certain microbial activities in a way that cannot be due to heat alone. 
Therefore, it has been suggested that microwaves could cause some changes in microbiological systems which cannot be wholly explained by the thermal energy generated by dielectric molecules (3).

TAOUKIS et al. (4) reported that thawing of frozen raw materials is integral to many food manufacturing processes. It is important to optimize thawing rates in order to avoid microbial problems, chemical deterioration and water loss due to dripping or dehydration. The development of microwave equiment that achieves a more uniform power distribution and a better control of microwave heating by combining lower frequency microwave generation with convection heating or cooling allows the exploration of such systems on an industrial scale. Tempering or partial thawing of meat products with microwaves prior to processing is currently practiced (5).

Freezing itself, if performed sufficient rapidly, has little demonstrable effect upon colour, flavour, odour or juiciness of meat after cooking. Frozen storage, however, results in a gradual decrease in odour and flavour acceptability. The methods of freezing and of packaging and the storage time and temperature have a significant effect on the maintenance of a satisfactory quality level. Tight-fitting, moisture-proof packaging and constant storage temperatures of $-18^{\circ} \mathrm{C}$ or lower are the most critical requirements. Odour and flavour changes occur mainly in the fatty constituents of meat, pork being more susceptible to such changes than beef or lamb. Microwave and dielectric heating can be employed to effect rapid thawing $(6,7)$.

The effect of packaging material on the storage properties of mechanically deboned meat has not been extensively studied. On the other hand, extensive information is available on the packaging of fresh meat. For example, it has been shown that microbiological spoilage is at its lowest when controlled atmosphere packaging in a carbon dioxide atmosphere is used (8). The second best alternative is a vacuum pack, followed by packing under ni- trogen, and the worst alternative is unpackaged meat.

Studies have also shown $(8,9)$ that carbon dioxide retards bacterial growth significantly, and that oxygen stimulates microbial growth. The amount of oxygen in a vacuum pack must therefore be minimized and the meat should be fresh. Some carbon dioxide is then formed in the pack by the action of the small numbers of microorganisms present in the meat.

De ZutTER and van Hoof (10) studied the microbiological characteristics of the fluid exuded from beef in a vacuum pack, and showed that the fluid is very susceptible to microbiological spoilage even during a short storage period. The effects of lactic acid bacteria, and the penetrability of the packaging material during the deterioration of vacuum packaged beef have also been studied. Vacuum packaged beef was shown to deteriorate at $+5^{\circ} \mathrm{C}$, even in the absence of noticeable microbial contamination. The meat spoiled, although it was vacuum-packaged in a film with poor oxygen penetration properites $\left(1 \mathrm{~cm}^{3}\right.$ $\mathrm{O}_{2} / \mathrm{m}^{2} / 24 \mathrm{~h} / \mathrm{atm}$ ) and the spoilage rate increased with the penetrability of the packaging material (11).

Even a three week storage period could be achieved with a vacuum pack, if the storage temperature was $+1 \ldots+3^{\circ} \mathrm{C}(12)$.

Mechanical deboning is more economical than hand boning. Because all the meat can thus be recovered and used in meat products, the aim of this invetigation was to evaluate the effect of thawing conditions on the quality of frozen, mechanically deboned meat.

\section{Materials and methods}

\section{Experimental Procedure}

The research was carried out at the production plant Osuusteurastamo Karjaportti in Mikkeli, and at the Finnish Meat Research Centre in Hämeenlinna. The machine used in the tests was a pressure type Inject Star (P-60) deboning machine (Hollstein-Fuhrman, Vienna, Austria). 
Table 1. The origin of bone, sample coding and the duration of frozen storage.

\begin{tabular}{|c|c|c|c|c|c|}
\hline Samples & $\begin{array}{l}\text { MDB } \\
\text { MDP }\end{array}$ & \multicolumn{2}{|c|}{ Beef, from bones of cows } & & \\
\hline $\begin{array}{l}\text { Duration of frozen } \\
\text { storage (weeks) }\end{array}$ & 4 & 8 & 12 & 16 & 20 \\
\hline Analysed samples & MDP & MDP MDB & MDP MDB & MDP MDB & MDB \\
\hline
\end{tabular}

Mechanically deboned meat samples were recovered in a freshly disinfected machine, and immediately packaged in $3 \mathrm{~kg}$ samples in plastic-coated cartons (HDPE-plastic) and in Cryovac vacuum bags. The conditions used were; temperature of bones to be processed $+6^{\circ} \mathrm{C}$, freezing temperature $-40^{\circ} \mathrm{C}$, utilization of freezing air $98000 \mathrm{~m}^{3} / \mathrm{h}$ in $6900 \mathrm{~m}^{3}$, frozen storage temperature $-24^{\circ} \mathrm{C}$.

Table 1 shows the origin of the bones, sample coding and the time in the freezer storage. The recovering temperature immediately after separation was $+4^{\circ} \mathrm{C}$.

\section{Thawing conditions:}

1) microwave thawing

2) thawing at $+4^{\circ} \mathrm{C}$

3) thawing at $+21^{\circ} \mathrm{C}$

In microwave thawing, a Husqvarna Mikronet $(650 \mathrm{~W})$ microwave oven was used. Packaged samples were first thawed for 15 minutes. Heating was stopped for 10 minutes, after which it was repeated for 15 minutes.

The samples thawed in microwave oven, at $21^{\circ} \mathrm{C}(18 \mathrm{~h})$ and at $+4^{\circ} \mathrm{C}(42 \mathrm{~h})$ were analysed immediately after thawing.

\section{Measured parameters:}

chemical; fat, protein, ash, calcium, phosphate and bone particle content, $\mathrm{pH}$, peroxide value, free fatty acids (FFA \%), thiobarbituric acid value (TBA value), connective tissue content and water holding capacity, physical; colour,

microbiological; aerobic bacteria count, coliforms $37^{\circ} \mathrm{C}$, coliforms $44^{\circ} \mathrm{C}$ and lactic acid bacteria

\section{Evaluation of the quality of mechanically deboned meat}

Methods used for evaluation of the quality of mechanically deboned meat were as presented earlier by RIIHONEN $(13,14)$.

\section{Statistical analysis}

The results were analysed statistically using a Multiplan graph method and the WindowsExel graph programme. The three-dimensional 3D Graph programme was also used. Analyses were carried out from three samples in duplicate. Standard deviations were calculated for all the variables studied during storage. Two tailed t-tests were used to evaluate differences between the various thawing conditions.

\section{Results and Discussion}

The composition of the MDM and MDP samples used is presented in Figure 1 and the effects of thawing on a frozen sample of MDB in Figures 2-3 and of MDP in Figures 4-5. A rapid rise in the population of bacteria was detected in the vacuum-packaged samples thawed at $+21^{\circ} \mathrm{C}$ temperature (Figs. 3 and 5). The difference between microwave thawing and thawing at $+21^{\circ} \mathrm{C}$ was significant $(\mathrm{P}<0.05)$. This was also indicated as a falling in $\mathrm{pH}$ from 6.05 to 5.80 in MDB and from 6.33 to 6.20 in MDP samples $(\mathrm{P}<0.05)$. This is in agreement with the observation of NEw. SOME et al.(15), who showed that vacuum packaging causes a shift in the microflora from a predominance of aerobic spoilage organisms to lactic acid bacteria. As a result of 


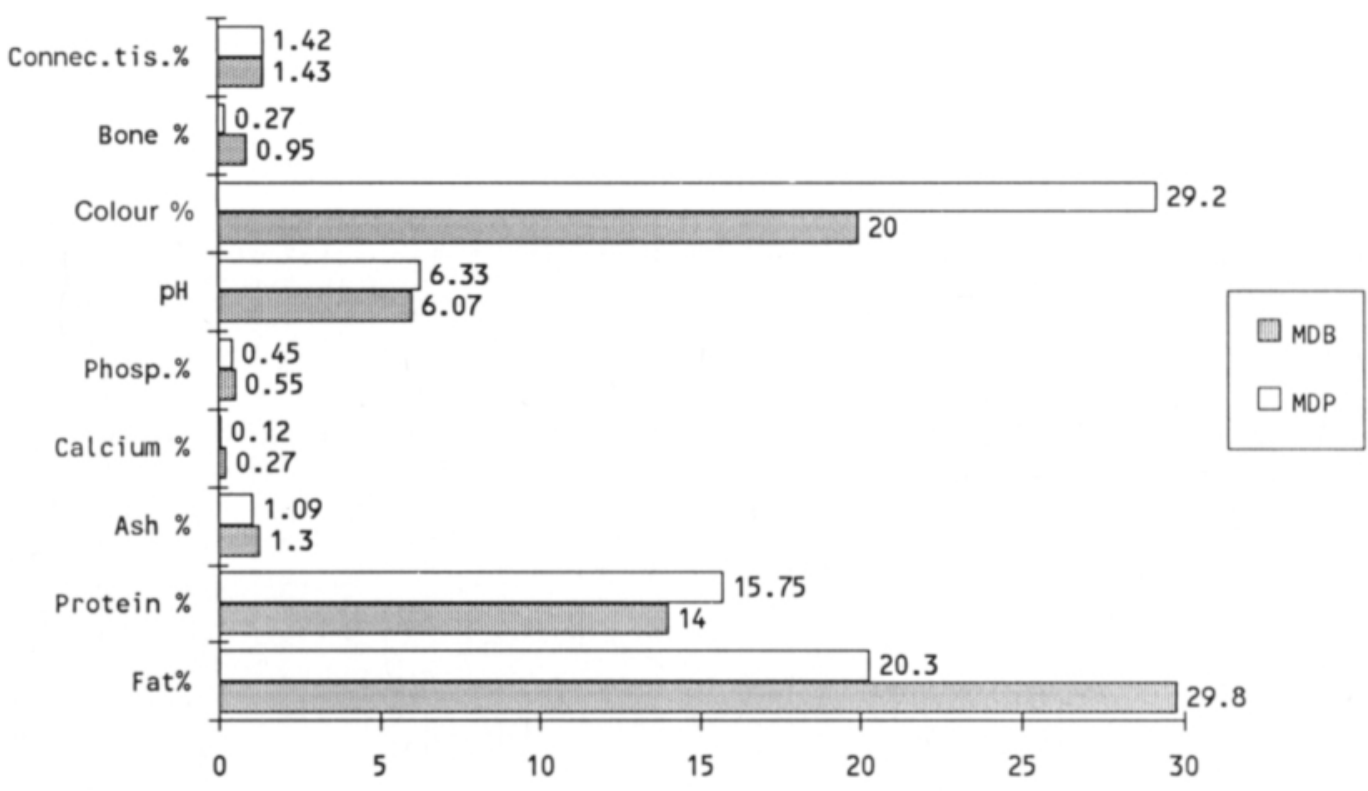

Fig. 1. The composition of mechanically deboned beef (MDB) and pork (MDP). Connect.tis\% is the connective tissue content and phosp. $\%$ is the phosphate content.

the impermeability of the packaging film, carbon dioxide builds up inside the vacuum package. The change in atmosphere within the vacuum package causes a decrease in the percentage of aerobic organisms, such as pseudomonads, and an increase in the percentage of lactic acid bacteria (Figs. 3 and 5). Standard deviations varied in MDB samples from 0.14 to 0.33 and in MDP samples from 0.13 to 0.33 . Differences between microwave thawing and thawing at $+21^{\circ} \mathrm{C}$ and $+4^{\circ} \mathrm{C}$ were significant $(\mathrm{P}<0.05)$. Some lactic acid bacteria may even be stimulated by increased carbon dioxide concentrations (8). Moreover, lactic acid bacteria are capable of producing organic acids, hydrogen peroxide, and/or bacteriosides which may further inhibit spoilage microorganisms.

When the samples were thawed at $+21^{\circ} \mathrm{C}$ the free fatty acid (FFA-\%)-value in MDPsample was the highest, 1.46 after 16 weeks $(\mathrm{P}<0.05)$.

No samples packed in vacuum bags were available in the thawing at $+4^{\circ} \mathrm{C}$ after storage for 16 weeks (Fig. 4A).
After 12 weeks of frozen storage the FFA-\%-value of the MDB sample had increased from 0.66 to 0.90 in samples packaged in vacuum bags and thawed at $+21^{\circ} \mathrm{C}$ (Fig. 2A). Standard deviations varied from 0.04 to 0.27 . The trend continued to a storage time of 16 weeks. Thiobarbituric acid (TBA)-values did not vary significantly under different thawing conditions (Figs. 2B and 4B). Standard deviations varied from 0.02 to 0.37 .

The difference between vacuum packaging and carton packaging was clearest when analysing the peroxide results. For example, peroxide values $(\mathrm{meqO} / \mathrm{kg}$ ) of mechanically deboned pork (MDP) after four weeks of frozen storage in cartons were 1.22 when thawing with microwave and 1.13 and 0.87 , respectively when thawing at $+21^{\circ} \mathrm{C}$ and $+4^{\circ} \mathrm{C}$. The corresponding figures for samples stored in vacuum bags were $0.74,0.41$ and 0.36 . The peroxide values after 16 weeks of frozen storage were $2.63,3.95$ and 2.67 in cartons and $0.77,0.45$ and (no results) in vacuum bags (Figs. 2C and 4C). Standard deviations of the results varied from 0.03 to 0.78 . MDB-sam- 


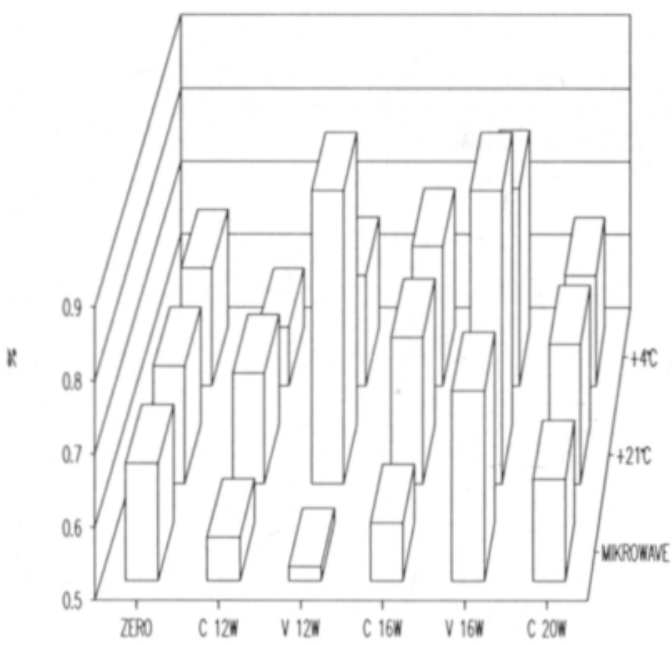

a

TNE/seck

Fig. 2. Comparison of different methods of thawing of condition in MDB. Analysis by A) free fatty acid value (FFA \%), B) thiobarbituric acid value (TBA mg/kg) and C) peroxide value (milliequivalent oxygen $/ \mathrm{kg}$ ). $\mathrm{ZERO}=$ results after one day, $\mathrm{C}=$ carton packaging and $\mathrm{V}=$ vacuum packaging, e.g. $12 \mathrm{CW}=$ carton packaging after 12 weeks' storage. Mean values of three replicates carried out in duplicate.

ples were also analysed after 20 weeks of frozen storage, but analysis of the MDP was discontinued after 16 weeks, because of the poorer keeping qualities of the pork.

The number of bacteria in meat may increase by contamination during freezing operations. However, freezing kills a small proportion of all the microorganisms present in meat; more of them die during frozen storage, but

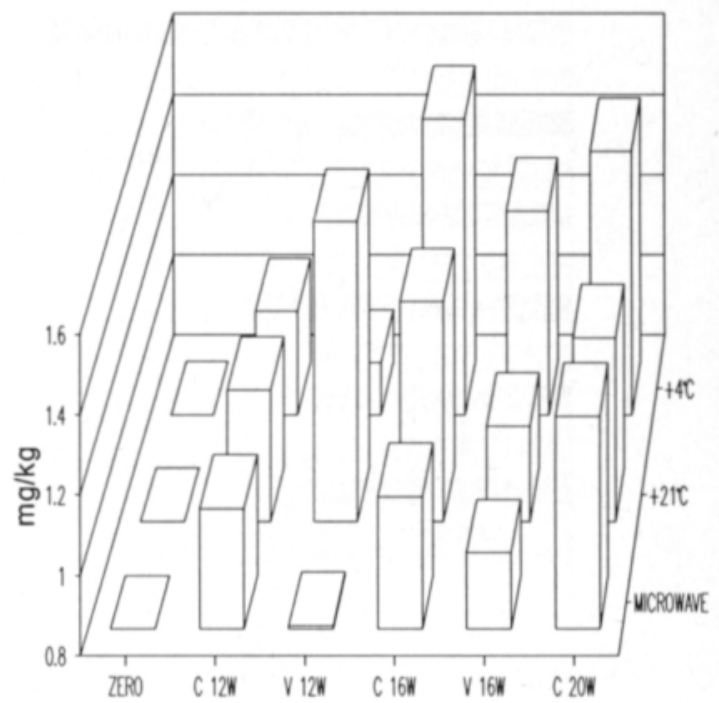

b
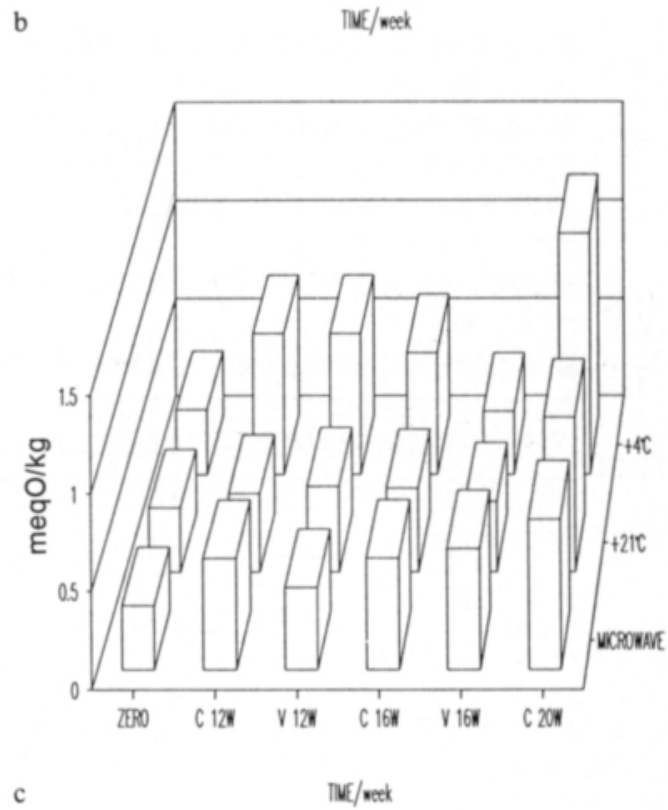

this process occurs rather slowly (approximately $5 \%$ of the population per month) at temperatures of about $-20^{\circ} \mathrm{C}$. Gram-negative rods are more susceptible than gram-positive cocci. Spores remain unaffected, whereas e.g. vegetative cells of Clostridium perfringens die rapidly. Dispite these effects bacterial levels may be very high in thawed beef. The time required for thawing of frozen meats depends 

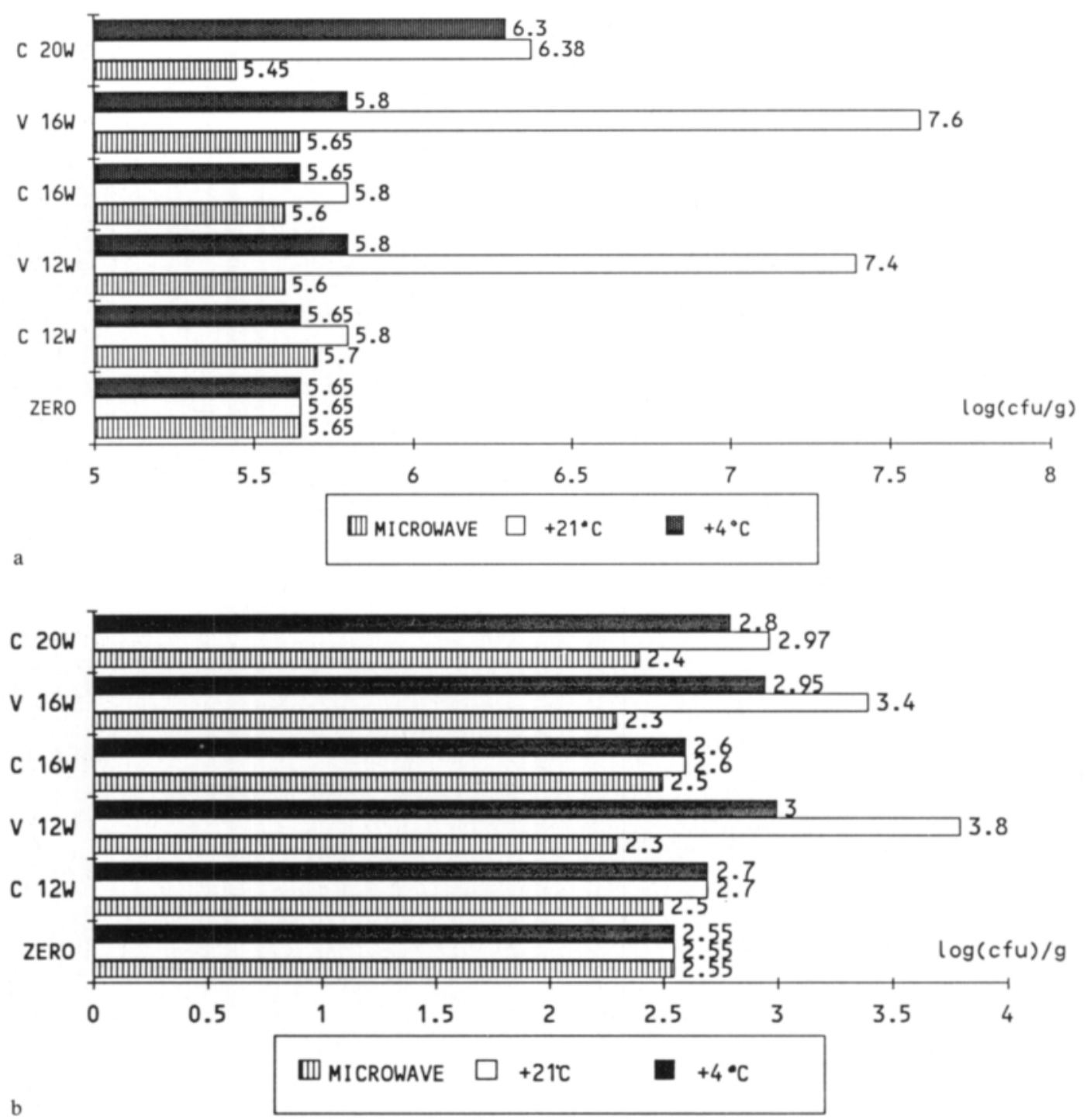

Fig. 3. A) The aerobic microbial counts, $\log (\mathrm{cfu} / \mathrm{g})$ and $\mathrm{B})$ the lactic acid bacterial counts, $\log (\mathrm{cfu} / \mathrm{g})$ as a function of the method of thawing of MDB. ZERO = results after one day, $\mathrm{C}=$ carton packaging and $\mathrm{V}=$ vacuum packaging, e.g. $12 \mathrm{CW}=$ carton packaging after 12 weeks' storage. Mean values of three replicates carried out in duplicate.

on the temperature of the meat and its thermal capacity, the thawing medium and its temperature and circulation, the size of the unit being thawed, and other lesser factors (6, 7). Although microorganisms do not grow faster on thawed meat than on fresh meat, the product is very perishable as soon as the surface temperature increases above $0^{\circ} \mathrm{C}$.

It is often stated that thawed meat is more perishable than fresh meat that has never been frozen, because of the drip exuded from thawed meat, which is a good medium for microbial growth. However, the growth rate of bacteria on thawed meat is not very different from the rate on equivalent non-frozen meat. Meat that has been frozen and thawed in commercial practice, however, commonly carries much more bacteria than the equiva- 


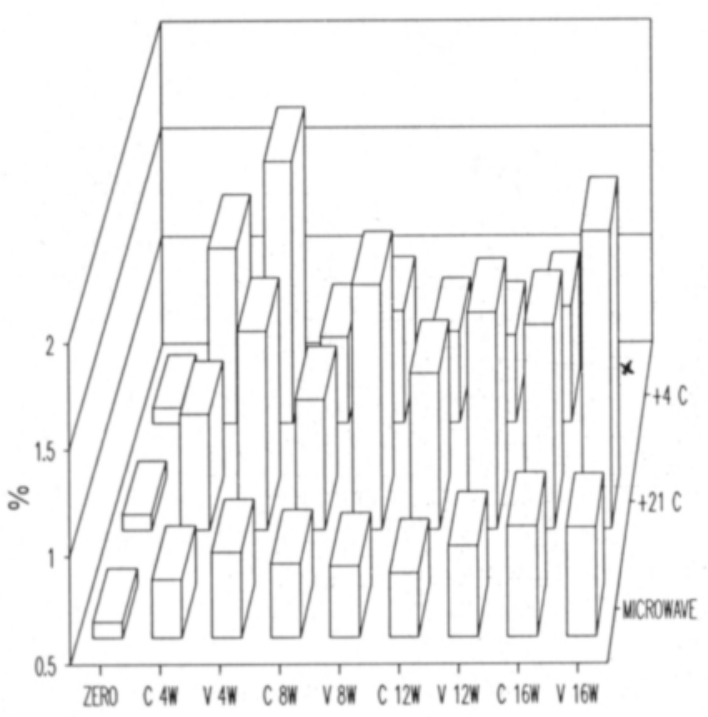

a

TNE/ neek

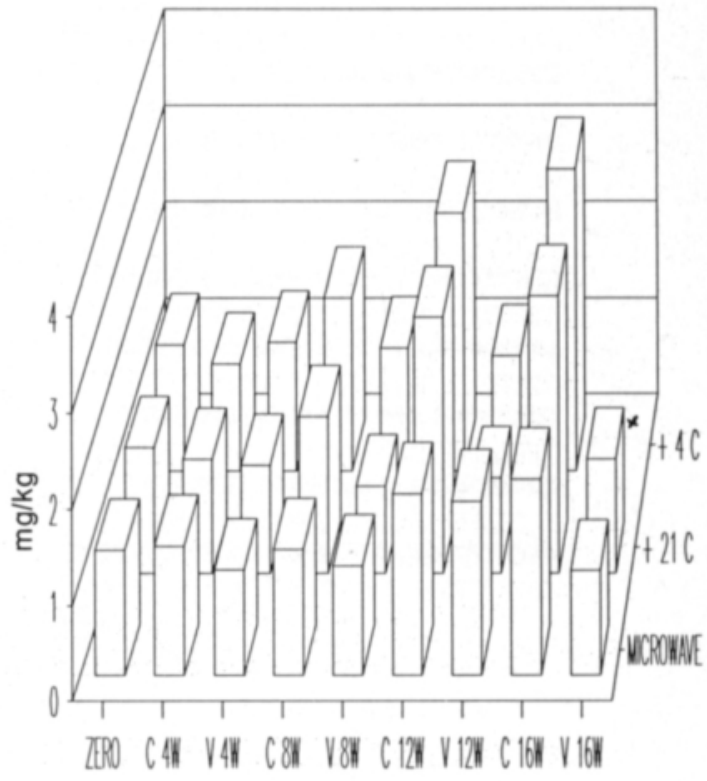

The/noth

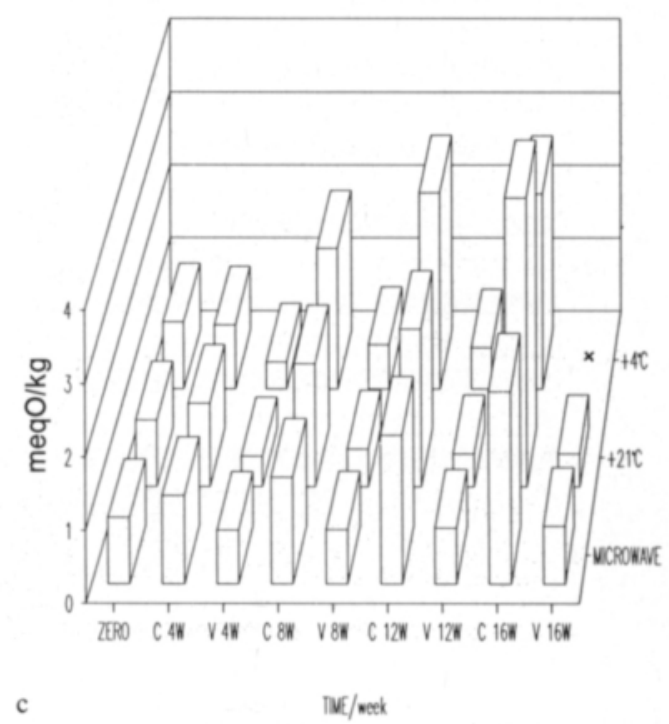

room temperature $\left(20^{\circ} \mathrm{C} / 1\right.$ hour $)$, at $+4^{\circ} \mathrm{C}$ temperature (10 hours) and in a microwave oven $(2-3 \mathrm{~min})$. Thawing at room temperature was significantly the poorest method. This is in agreement with the results of this work, in which it was concluded that micro-

b

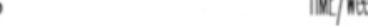

Fig. 4. Comparison of different methods of thawing of MDP. A) free fatty acid value (FFA \%) B) thiobarbituric acid value (TBA-value) and $\mathrm{C}$ ) peroxide value (milliequivalent oxygen $/ \mathrm{kg}$ ). $\mathrm{ZERO}=$ results after one day, $\mathrm{C}=$ carton packaging and $\mathrm{V}=$ vacuum packaging, e.g. $12 \mathrm{CW}=$ carton packaging after 12 weeks' storage. Mean values of three replicates carried out in duplicate. $x=$ no results.

lent fresh meat, leading for this reason to a shorter shelf life.

Puolanne and KukKonen (16) studied the effects of freezing of meat on the water-binding capacity of cooked sausage. Lean ground beef was frozen in plastic bags and thawed at 

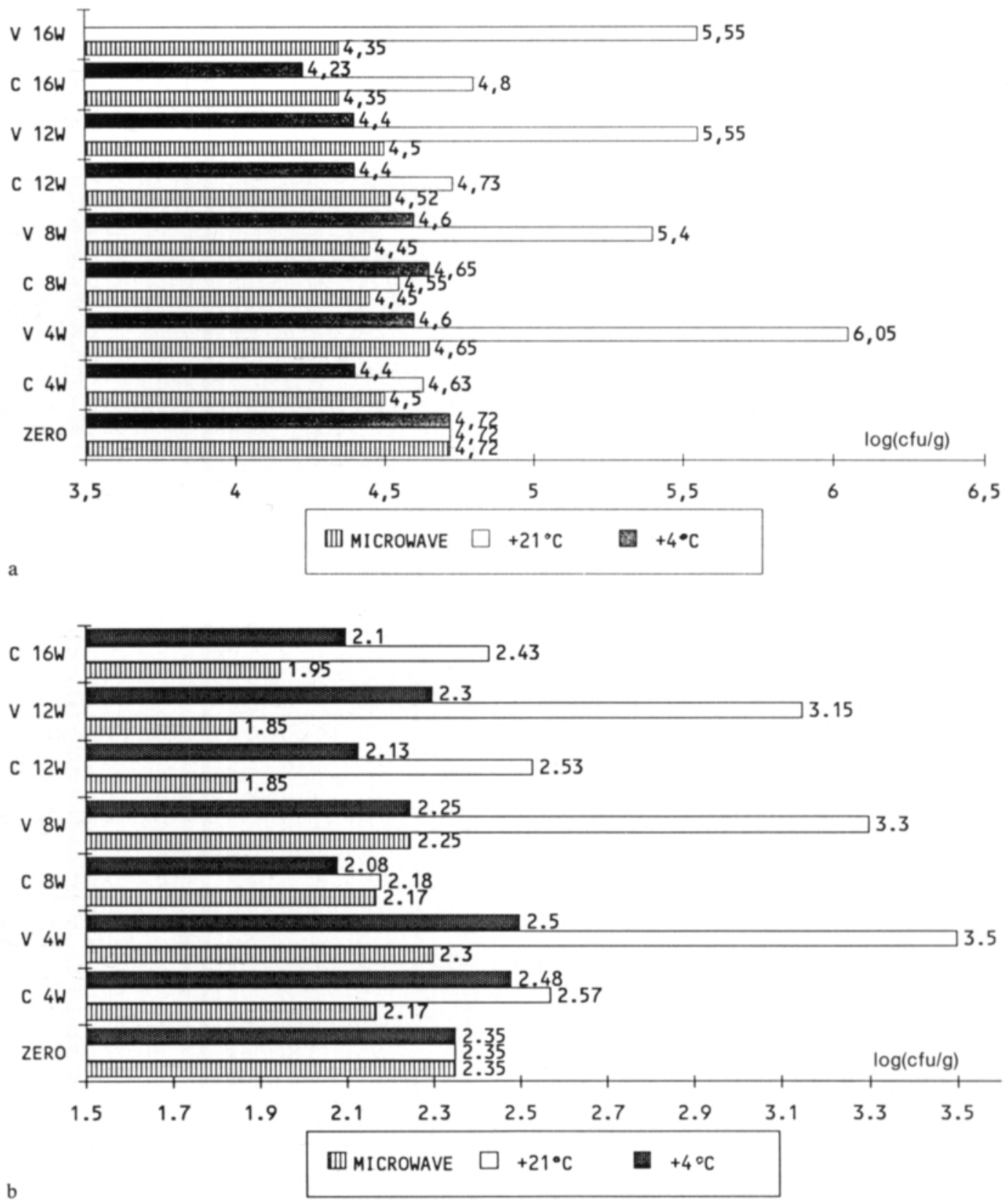

Fig. 5. A) The aerobic microbial counts, $\log (\mathrm{cfu} / \mathrm{g})$, and B) the lactic acid bacterial counts, $\log (\mathrm{cfu} / \mathrm{g})$ as a function of the method of thawing of MDP. ZERO = results after one day, $\mathrm{C}=$ carton packaging and $\mathrm{V}=$ vacuum packaging, e.g. $12 \mathrm{CW}=$ carton packaging after 12 weeks' storage. Mean values of three replicates carried out in duplicate.

wave thawing was the best alternative of the techniques used. The vacuum-packaged samples showed the least changes. Microwave irradiation has the potential to accelerate the thawing process, preferably in a continuous operation. However, the fear of localized overheating has limited the application of microwave thawing to food systems which require larger manufacturing volumes.

Acknowledgements. The authors are grateful to Osuusteurastamo Karjaportti for sponsoring this investigation. 


\section{References}

1 Selmeci, G., Cseh, F., Juhasz, I., Rosa, L. and SanTA, I., 1983. Analysis of mechanically deboned meat /MDM/. Effecet of microwave treatment on meat paste parameters. Proc. 29th Eur. Meet. Meat Res. Work., Panama, pp. 793-795

2 Decareau, R.V., 1985. Microwaves in the food processing industry. Academic Press, Orlando, London, pp. 182-202

3 Fung, D.Y.C. and Cunningham, E., 1980. Effect of microwaves on microorganisms in foods. Journal of Food Protection, 43: 641-650

4 Taoukis, P., Davis, E.A., Davis, H.T., Gordon, J. and TALMON, Y., 1987. Mathematical modelling of microwave thawing by the modifield isotherm migration method. J. Food Sci. 52: 455-458

5 Decareau, R., 1986. Pasteurization and sterilization, microwave food processing equipment throughout the world. Food Technol. 40(6): 99-105

6 Cleland, A.C. and Earle, R.L., 1984. Assessment of freezing prediction methods. J. Food Sci. 49: 1034-1037

7 Price, J.F. and Schweigert, B.S., 1987. The Science of Meat and Meat Products. Protective packaging of meat and meat products. Westport, pp. 489-505

8 Ahvenainen, R., 1989. Gas packaging of chilled meat products and ready to eat foods. Technical Research Centre of Finland, Publications 58, Helsinki pp. $49-50$

\section{SELOSTUS}

\section{Sulatusolosuhteiden vaikutus pakastetun mekaanisesti luista erotetun lihan laatuun}

\author{
L. Riihonen, ${ }^{*}$ ja P. Linko** \\ * Lihateollisuuden tutkimuskeskus \\ PL 56, SF-13101 Hämeenlinna, Suomi \\ ** Biotekniikan ja elintarviketeknologian laboratorio \\ Kemian tekniikan laitos \\ Teknillinen korkeakoulu, SF-02150 Espoo, Suomi
}

Työssă tutkittiin sulatusolosuhteiden vaikutusta pakastetun paineeseen perustuvalla Inject Star koneella erotetun naudan ja sian lihan laatuun.

Näytteet otettiin koneellisesti luista erotusta lihasta ja pakattiin kolmen kilon näyte-erissä HDPE-vuorattuihin laatikoihin ja Cryovac-vakuumipusseihin. Tutkimuksessa
9 Kastner, C.L. and Kropf, D.H., 1986. Processed meat products and safety issues. Dairy and Food Sanitation, 6 186-193

10 De Zutter, L. and van Hoof, J., 1982. Bacterial growth in exudate of vacuum packed beef. Proc. 28th Eur. Meet. Meat Res. Work., Madrid, pp. 355-356

11 Egan, A.S. and Shay, B.J., 1982. Sicnificance of lactobacilli and film permeability in the spoilage of vacuum-packaged beef. J. Food Sci. 47: 1119-1122

12 TÃndler, K., 1982. Hygiene im Zerlege- und Abpackbereich Teil 1, Die Fleischerei 33: 772-780

13 Rimonen, L., Laine, J. and KärkKäinen, T., 1990. Storage properties and quality of meats deboned by different methods. J. Agric. Sci. Finl. 62: 381-395

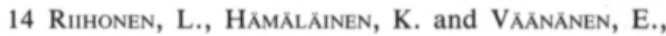
1990. Applications of mechanically deboned meat in sausage mass. J. Agric. Sci. Finl. 62: 397-405

15 Newsome, R.L., Seman, D.L., Langlois, B.E., Woody, W.G., Fox, J.D. and GAY, N., 1987. Microbiological quality of restructured and conventional steaks manufactured from electrically stimulated hotand coldboned carcasses. J. Food Sci. 52: 861-864

16 Puolanne, E. and KukKonen, E., 1982. The effect of meat freezing on water binding capacity of cooked sausage. Proc. 28th Eur. Meet. Meat Res. Work., Madrid, pp 146-148

Deb Ms received July 121990 käytettiin kolmenlaista sulatustapahtumaa; mikroaaltosulatus, sulatus $+4^{\circ} \mathrm{C}$ :ssa ja sulatus $+21^{\circ} \mathrm{C}$ :ssa. Näytteet analysoitiin kemiallisin ja mikrobiologisin menetelmin vălittőmåsti sulamisen jălkeen. Mikroaaltosulatus osoittautui muita menetelmiă paremmaksi $(\mathrm{P}<0.05)$. 